\title{
The Role of Combined Community Resilience Capacity on the Performance of Food Security Projects in Loima Sub County, Turkana County, Kenya
}

\author{
EkiruN. Mark \\ $\mathrm{PhD}$ Candidate, School of Open and Distance Learning \\ University of Nairobi, Kenya \\ Prof. Dorothy N. Kyalo \\ Professor, Senior Lecturer \\ School of Open and Distance Learning \\ University of Nairobi, Kenya \\ Dr. Angeline S. Mulwa \\ Lecturer, School of Open and Distance Learning \\ University of Nairobi, Kenya
}

\begin{abstract}
In spite of efforts by state and non-state agencies to respond to crisis in the horn of Africa, underlying vulnerabilities and low resilience capacities have resulted into chronic food insecurity among majority of the populations in the region. The goal of this paper was to examine the role of community resilience capacity on food security in Loima within Turkana County. The study used descriptive research design to examine the food security situation and existing resilience capacity in the community and correlational design to measure the relationship between the variables on the performance of food security projects. The main instruments of data collection for the study were semi-structured questionnaires, interview guides and observation check lists. The sample size for the study was 491 households administered across 11 sub locations of the sub county. Community resilience variables included: social capital, social safety nets, disaster management skills, resource capacity and external environmental factors. Performance of food security projects was measured in relation to the four standard dimensions and elements of food security. The results of the study highlighted that performance of food security projects has a moderate positive correlation with community resilience capacity of $r$ value $=0.458, R 2=0.1633$. Disaster management skills had the highest correlation coefficient with social safety net having a relatively weak correlation coefficient. Majority of the households were vulnerable, partly due to their over-reliance on relief food, frequency of disasters, and lack of livelihood diversification. Other cause of vulnerabilities is the inadequate strategic and policy instruments for the long term, sustained support. Social safety net programs were not robust enough to enhance resilience against the impacts of severe shocks. The study concludes that households with combined resilience capacity were less likely to be trapped in food insecurity than those who didn't adopt the strategies.
\end{abstract}

Keywords: Community, Resilience capacity, Food Security Projects

\section{Introduction}

Pastoralist's communities in developing countries often face a wide range of recurring and unanticipated disasters. The welfare costs of such disasters are often significant and draw policy and humanitarian attention (USAID, 2011). In spite of efforts by international community as well as governments to respond to these crises, underlying vulnerability conditions in the region have continued to accelerate food insecurity. While the efforts to respond to these disasters have saved lives, they have not done enough in enhancing community's resilience capacity so that households and communities in the region can avert future crises (FAO, 2008).

Since the term resilience was put forward by Holling (1973), it has since been adopted by many development practitioners in trying to comprehend the complexity of food systems and their ability to adapt during disasters (Constas et al., 2016).Fan et al., (2014) affirms that understanding resilience in household food systems may help in better performance of projects that are geared towards addressing food insecurity in shock-prone developing regions. Resilience has been defined from a socio-ecological approach as the "ability of individuals, systems, and communities to anticipate, absorb, adapt to, and recover from disruptions" (Pasteur 2011).

Resilience has been applied in various contexts including economy as well as engineering, in economy for instance, it has been applied in trying to understand whether and how social and economic systems could become more robust to shocks (Barrett and Constas 2014). Few studies have emerged on specific application of resilience to food security/insecurity; most of these studies tend to treat the topic from a general perspective (Toth et al., 2016). 
The objective of this paper is to examine the influence of community resilience capacity on food security in Loima within Turkana County. Due to recurrent drought, most households in Loima have experienced persistent hunger and starvation. Despite efforts by the Government of Kenya and international community in providing relief food to the people of the region for decades the situation of food security has remained a challenge in the region (Opiyo et al., 2015). Some of existing community coping strategies among the pastoralist communities are unsustainable and they include skipping meals, migration as well as borrowing from neighbors (Tolossa, 2018). This paper therefore analyzed the existing community resilience in trying to understand how they influence the performance of food security projects. Through the gaps identified, the paper proposes sustainable measures to cushion vulnerable households to be able to maintain a certain level of well-being in the face of risks.

\section{Literature Review}

To achieve the research objectives, literature review of various components of resilience and food security was systematically conducted. The components of resilience reviewed include: community social capital, social safety nets, disaster management skills, community resource capacity as well as external environmental factors.

The most accepted definition of food security is the one suggested by the 1996 World Food Summit where food security is defined as access by all people at all times to adequate nutritious food for an active and healthy life (Von Braun et al., 1999). The definition further outlines four important dimensions of food security: food availability; food access; utilization, and stability. Maxwell et al., (1992) in his conceptual review of household food security further identified three more important paradigm shifts in understanding of the food security concept. The first shift is from global, national to household focus. The second shift is from the "food-first" thinking to a livelihood perspective while the third shift is about livelihoods during shocks and how people themselves respond to perceived risks and uncertainties. In this paper performance of food security projects is assessed from the four dimensions of food availability, food access, food utilization and food stability.

The term resilience as first introduced by C.S. Holling (1973) is defined as the capacity of a system, or amount of disturbance a system can absorb without shifting into an alternate state and has the ability to regenerate after disturbance (Walker et al., 2006), (Resilience Alliance, n.d.). Recently the concept of resilience has been expounded to include complex systems such as food and livelihood systems (Alinovi et al., 2010). Despite the burgeoning of literature on resilience, there is no common understanding on standard definition of the subject by different disciplines. For example, Miller et al., (2010) in his review of the subject resilience noted that ecologists tend to focus on the physical vulnerability and resilience of ecosystems and their services while social scientists tend to focus on social aspects such as access to assets, social support systems rather than interconnections between social and ecological systems. However, for this purpose of this study, the term resilience is used to describe the ability of individuals and communities to absorb, adapt to and recover from hazards, shocks or stresses without compromising long term prospects of development.

Frankenberger et al., (2012) describe resilience as an outcome as well as a process. As an outcome resilience measurement can be in-form of food and nutritional outcome while as a process resilience can be well understood as changes in resilience capacity over time (Vaitla et al., 2012).Based on the review on community resilience to shocks and stressors, this paper adopted the following indicators of resilience; social capital, social safety nets, community resource capacity, ownership of assets, disaster management skills and environmental factor influence.

Nyanjom (2014) in his publication on "re-marginalizing Kenyan Pastoralists" recognized the importance of social capital in cushioning the Kenyan pastoralists against the impacts of recurrent drought. According to Nyanjom, social capital is 'the networks and relationships that people develop and use to build trust and enable them to work together effectively and efficiently. Chambers and Conway (1992), understands social capital from the formal and informal institutions interactions point of view. According to Chambers and Conway, social capital entail: associations, extended family and local mutual support mechanisms or networks that cushion the household against the adverse effects of the disaster.

Barbier and Hochard (2014) further helps in understanding of social capital as social relations which offers a dynamic space for people to interact and pursue individually as well as collective objectives for communal wellbeing. Alonso (2015) in his study on "the impact of culture, religion and traditional knowledge on food and nutrition security in developing countries" did affirm that community social capital coupled with traditional knowledge determined intra-household food distribution patterns, which therefore affects availability. According to Alonso (2015), Social capital can positively and negatively affect community resilience to disasters.

Despite recognition of interpersonal trust and networks in coping with variety disasters, allowing a few people to enjoy the benefits of closely-knit communities jeopardizes the resilience of the excluded.

Social safety net is another important component of resilience to food insecurity. Social safety nets are simply the programs that help the poorest and most vulnerable people stay out of extreme poverty by providing them with transfers which could be in kind, vouchers or cash to cushion them from adverse effects of a crisis (Brunson, 2017). 
In Africa, a study byBehnke (2008) on economics of pastoralism in the Horn of Africa suggests that the status and evolution of social safety net in and after 1970s has been worse as almost all measures found are quite short-term measures and thus unsustainable, such as emergency food aid, famine relief, and humanitarian assistance. However, in countries such as Kenya, Zambia, Malawi, Uganda, Ghana, and Nigeria, social protection programs have started to transform from the short-term solutions to more long-term initiatives such as cash transfer (Devereux, 2016).

Kenya initiated her first social safety net program in form of Cash Transfer to Orphans and Vulnerable Children in 2005, the program was later piloted in 2006 and 2008. This created a receptive environment for establishment of hunger safety net program by the Kenyan government through support from the World Bank (Devereux, 2016). An evaluation of the hunger safety net program in Kenya by Sophie and Katsushi (2019) indicated that 30\% of the poverty reduction was due to cash transfer while $70 \%$ as a result of economic growth. Case studies of Ethiopia, Kenya and Uganda, as well as wider social protection literature, confirm there is currently an evidence gap when it comes to social protection's contribution to long-term adaptation and resilience to food insecurity.

Ownership of assets is another component of resilience to food insecurity. Ownership of assets is an important indicator of economic strength. During hardships households tend to dispose some of their assets to get money for food and other life support basic needs. Sometimes these assets can be directly exchanged with food to cushion against hunger. Among the nomadic pastoralist livestock herds form an important asset. However, sometimes due to their migratory nature, few other assets are accumulated or owned. A study by Quandt(2018), on factors affecting rural households' resilience to food insecurity in Niger, using a sample of 9354 rural households confirmed the hypothesis that the more assets a household owns, the higher its level of resilience. Indeed, such assets can be used to buffer shocks. In relation to pastoralism, this paper tried to fill the existing research gap on the link between livestock and other natural based assets and resilience during hazards.

Community based disaster management skills forms another important component of resilience building capacity to food insecurity. Food insecurity and disaster risk reinforce one another. Disasters have shattering consequences on food security, and food-insecurity increases vulnerability, leading to a downward spiral in which rural livelihoods are increasingly eroded (Downing and Bakker, 2000).Disaster management skills varies from preparedness to rehabilitation. Communities with disaster preparedness skills and plans will be more resilient to impacts of disasters. Analysis of disaster management in Mozambique by (UN-OCHA, 2013) showed that after the government of Mozambique had invested in disaster preparedness by issuing timely alerts and established contingency plans, the impact of the recurrent floods was relatively small in terms of the number of people who died (OCHA, 2013).

Last but not least, external environmental factors are equally important components of resilience concept in analyzing food security. The external environmental factors are considered to be beyond individual households' capacity. Their categorization is based on environmental, political, social, economic, historical and demographic as well as policy conditions. All these aspects affect households and communities' ability to cope with adverse risk (Alinovi al., 2010).Changes in external environmental factors has a positive or negative impact on the ability of households or communities to cope with future risks and disasters.

In this paper, Theory of Constraints is applied to understand resilience properties in relation to performance of food security projects in Loima Sub-County of Turkana County. The theory of constraints (TOC) is an overall management philosophy introduced by Eliyahu M. Goldratt in his 1984 book titled 'The Goal" that was geared to help projects to achieve their goals. The theory of constraints is the belief that every project has a constraint or a bottleneck that hinders the project from achieving the targeted goals. The core concept of the Theory of Constraints is that every process has a single constraint and that total process throughput can only be improved when the constraint is improved.

A very important corollary to this is that spending time optimizing non-constraints will not provide significant benefits; only improvements to the constraint will further the goal. In food security projects the main constraints are related to; accessibility, and availability. This study uses theory of constraints to identify the level of influence of resilience capacities challenges on performance of the food security projects and suggest measures that key players in the sector can adopt.

The literature reviewed provide valuable insights into key variables on resilience and food security, but also points to an information gap that the current study seeks to fill regarding how resilience components influences performance of food security projects in Loima sub-County.

\section{Methodology}

This study is guided by pragmatism paradigm with mixed method research design. The pragmatic research paradigm is adopted based on Morgan (2006) argument that paradigms are a set of beliefs and practices that guide the researcher's choice of methods of research. Descriptive and correlational research designs were adopted for the study. The aim of the study is to establish the influence of combined community resilience capacity on the 8 
performance of food security projects, both qualitative and quantitative descriptive research design were used to describe the food security situation and existing resilience capacity in the community while correlational design was used to measure the relationship between the variables on the performance of food security projects.

To avoid misinterpretation, the interviews and discussions were conducted in the local language generally understood by the respondents. The unit of analysis in this study was the households; their analysis was categorized in reference to the 31 existing sub-locations in the study area. Selection of sub-locations for the study was guided by Slovin's formula which led to random selection of $35 \%$ of 31 sub-locations for the study. Sample size for the households was obtained using Slovin's formula denoted by the population size and the acceptable margin of error of 0.05 as indicated in the following formula:

$$
\begin{aligned}
& \text { Sample Size }(\mathrm{n})=\frac{N}{1+N e^{2}} \\
& \text { Where: } \\
& n=\text { Number of samples } \\
& \mathrm{N}=\text { Number of Households } \\
& \mathrm{e}=\text { Marginal error }(0.05) \\
& \text { Sample Size }(n)=\frac{16,517}{1+16,517 * 0.05^{2}}=390.54 \cong 391
\end{aligned}
$$

An extra 100 households were added to make the sample size to be 491 so as to take care of the sampling errors. The attained sample size was proportionately allocated to the 11 sub-locations. Purposive sampling was employed to get households that were beneficiaries of food security projects as well as to identify key informant interviewees who in this case are the project managers Mertens (2014).

The main instruments of data collection for the study were semi-structured questionnaires, interview guides and observation check lists. Information collected was on combined components of community resilience capacity, dimensions of food security, project management and socio-demographics. The research instruments were checked for validity to ensure that they measure correctly the intended constructs (Heale and Twycross, 2015). In this study the reliability of the instruments was taken at Cronbach's alpha coefficient of 0.8 , since it is greater than 0.7 .

Descriptive analysis was used to understand non-parametric data while inferential statistics were used to test the hypotheses which were further used to generalize the findings. The mathematical model used to test the null hypothesis is outlined in the following paragraph: $\mathrm{H}_{0} ;$ Community resilience capacity has no significant influence on the performance of food security projects in Loima Sub-County, Turkana County, Kenya.

\section{Regression model use to test the hypothesis of study}

Performance of food security projects $=\mathrm{f}$ (Community resilience capacity)

\section{Results}

$$
\begin{aligned}
& Y=\beta_{0}+\beta_{1} X_{1}+\beta_{2} X_{2}+\beta_{3} X_{3}+\beta_{4} X_{4}+\varepsilon \\
& \text { Where: } \\
& Y=\text { Performance of food security projects } \\
& X_{1}=\text { Social Capital } \\
& X_{2}=\text { Social safety nets } \\
& X_{3}=\text { Disaster Management skills } \\
& X_{4}=\text { Community resource capacity } \\
& \beta_{0}=\text { Constant term } \\
& \beta_{1}, \beta_{2}, \beta_{3}, \beta_{4}=\text { Beta coefficients } \\
& \varepsilon=\text { Error term }
\end{aligned}
$$

Loima is in a semi-arid region of Northern Kenya, pastoralism is the main livelihood in the area. The area has experienced recurrent drought in the recent past coupled with decades of marginalization which renders the pastoralist community vulnerable.

However, various projects have been initiated by both the county and the national government of Kenya and nonstate actors to cushion the local community against food insecurity and hunger. This study therefore analyzed the influence of combined community resilience capacity on performance of food security projects initiated in Loima sub-County in Turkana County of Kenya.

\subsection{Descriptive analysis of combined community resilience capacity}

For this study, five key components of combined community resilience capacity were analyzed; they include the social capital, social safety net programs, community resource capacity, disaster management skills as well as external environmental factors. 
In relation to social capital, bonding social capital which entailed horizontal links between family members, close friends and relatives was the most common type of social capital with $90.9 \%$ of the respondents indicating that it existed in their community. Bridging capital which was conceptualized as a network that connects members across communities and groups returned a 35.4\% indicating that it also existed but not majorly among the community members.

Linking capital which connects social networks vertically with some form of authority in the social sphere was the least with only $25.8 \%$ of the respondents indicating that it existed. With reference to how the social capital enhanced resilience capacity during disasters, $84 \%$ of the respondents believe that knowing each other leads to hospitable intercommunity and cross border migration which enabled them to move from one area to another in times of disaster, hence helping reduce food insecurity (Table 1).

Table 1: Social Capital and Resilience During Disasters.

\begin{tabular}{llll}
\hline Social Capital Variables & N & Frequency & Percentage \\
\hline Hospitable intercommunity and cross border migration & 418 & 351 & 84.0 \\
Market access and trading & 418 & 190 & 35.4 \\
Sharing of community resources & 418 & 133 & 31.8 \\
Sharing of information and knowledge & 418 & 181 & 43.3 \\
\hline
\end{tabular}

Other important social capital which enhanced resilience building is illustrated in Table (1). They include market access and trading, sharing of community resources and sharing of information and knowledge between communities and individuals during disasters. However, during the focused group discussions there were concerns of continuous weakening in social capital among the local community in Loima. Some stated reasons include; migration, modernity as well as politics. There also existed some social norms such as eating habits and preferences, polygamy as well as overreliance on pastoralism which inhibited community resilience capacity.

Data on safety net program indicated that only $14.4 \%$ (60) of the respondents had enrolled in a social safety net programs while the remaining $85.6 \%$ (356) were not enrolled in any social safety nets programs. Only a paltry $7.5 \%$ (31) of the respondents felt that the social safety nets programs had a high impact on their livelihoods and resilience to food insecurity. Some challenges mentioned on access to social safety nets include:

Low amounts being disbursed with $58.2 \%$ (242) of the respondents mentioning it, this was followed by frequent delays in disbursements as indicated by $40.4 \%$ (168) of the respondents. An inclusion and exclusion error in listing of the respondents was the least challenge with only $28.6 \%$ (119) of the respondents mentioning it.

In relation to disaster management skills component of resilience, respondents were asked to respond to questions by indicating their level of agreement with some given statements. The items were based on a 5-point Likert scale ranging from $5=$ Strongly Agree, $4=$ Agree, $3=$ Neutral, $2=$ Disagree, and lastly $1=$ Strongly Disagree. The responses are summarized in Table 2.

\section{Table 2: Disaster Management Skills}

\begin{tabular}{|c|c|c|}
\hline Statements & Mean & $\begin{array}{l}\text { Standard } \\
\text { Deviation }\end{array}$ \\
\hline We have mechanisms to foretell a disaster is coming & 3.58 & 1.24 \\
\hline We prepare to face a disaster when it is coming & 3.53 & 1.16 \\
\hline $\begin{array}{l}\text { We tend to absorb the shocks and stresses that combine to create disaster impact } \\
\text { whenever it occurs }\end{array}$ & 3.61 & 1.07 \\
\hline We tend to adapt to the recurrent shocks and stresses that create a disaster & 3.42 & 1.07 \\
\hline Quite often we get better after a disaster strikes & 2.96 & 1.19 \\
\hline We have preparedness and response structures in place & 3.24 & 1.15 \\
\hline We have mitigation mechanisms in place to reduce or avoid the impact of disaster & 3.63 & 1.22 \\
\hline We have access to trained personnel on disaster preparedness and response & 2.96 & 1.16 \\
\hline $\begin{array}{l}\text { We practice both modern and traditional coping and adaptation mechanisms to survive } \\
\text { effect of the shocks and stresses }\end{array}$ & 3.85 & 1.18 \\
\hline We have low physical and economic damage as a result of disasters & 2.98 & 1.17 \\
\hline Composite mean & 3.376 & 1.161 \\
\hline
\end{tabular}

From the focused group discussions, members stated that most of these skills disaster management skills were gained through training from various organizations as well as through their own experience with the disasters. 
However, not everyone in the community had disaster management skills. Drought was the major disaster in Loima Sub-County; the primary coping options include migratory labor, increasing livestock sales, borrowing money or food, switching to less preferred food items, and reducing non-essential expenditure items.

Land, livestock, water, minerals and oil were the main community resources in Loima Sub-County. Livestock, pasture, water pans were communally owned. Elders in the community controlled the use of these important resources. Majority of the respondents agreed that, there is adequate access to basic services such as health, education, water in their area (mean=3.56, $\mathrm{SD}=1.18$ ), there is good communication and information sharing on community needs and priorities (mean $=3.61, \mathrm{SD}=1.24$ ), community and household resources and assets such as livestock help to cushion against food security shocks (mean=3.56, $\mathrm{SD}=1.06$ ) and all community members have equal access to the use of available natural resources such as land, forests, water among others (mean $=3.89$, $\mathrm{SD}=1.11$ ). The overall mean of community resource capacity was found to be 3.33 with a standard deviation of 0.35 .

External environmental component of resilience entailed; political, socio-cultural, economic as well as legal. On political aspect, 91\% (395) of the study respondents believe that political process determined choice of projects, target location and beneficiary. Demands for kickbacks by local leadership for continuous support of the projects were last with $30 \%$ (130) of the respondents choosing it. The cultural component included failure to adapt to change for livelihoods diversification with $87.6 \%$ (380) respondents choosing it. Local beliefs and values attached to livestock waschosen by $41 \%$ (178) respondents, the role of men and women in food security projects was picked by $38.2 \%(166)$ respondents.

The economic aspects include: fluctuations of prices of basic commodities as supported by $60.8 \%(264)$, poor infrastructure and low purchasing power were also mentioned by $52.1 \%(226)$ and $44.9 \%(195)$ of the respondents respectively. Lack of awareness at household level on basic policies, regulation and laws that promote access to food as a basic human rights and lack of enforcement of existing legislation that promote food security were mentioned by $40.8 \%(177)$ and $40.6 \%(176)$ of the respondents respectively. After analyzing the key components of collective community resilience capacity the study further sought to understand performance of the food security projects in the study area.

\subsection{Descriptive analysis on performance of food security projects}

The performance of food security projects was analyzed in reference to four key components of food security i.e. food availability, food access, food utilization as well as food stability. The study assumes that if the respondents are food secure then the food security projects would be considered to be successful. Most food security projects in Loima were short term relief projects as mentioned by $(66.3 \%)$ of the respondents, Development projects were the second popular projects in the area of study given by $21.28 \%$, they included; natural resources management, income generation projects, skill and knowledge building and youth and women empowerment. Medium to long term projects accounted for $10 \%$ of the total respondents, these projects were; assets creation, savings and loans schemes, and irrigation schemes (Figure 1).

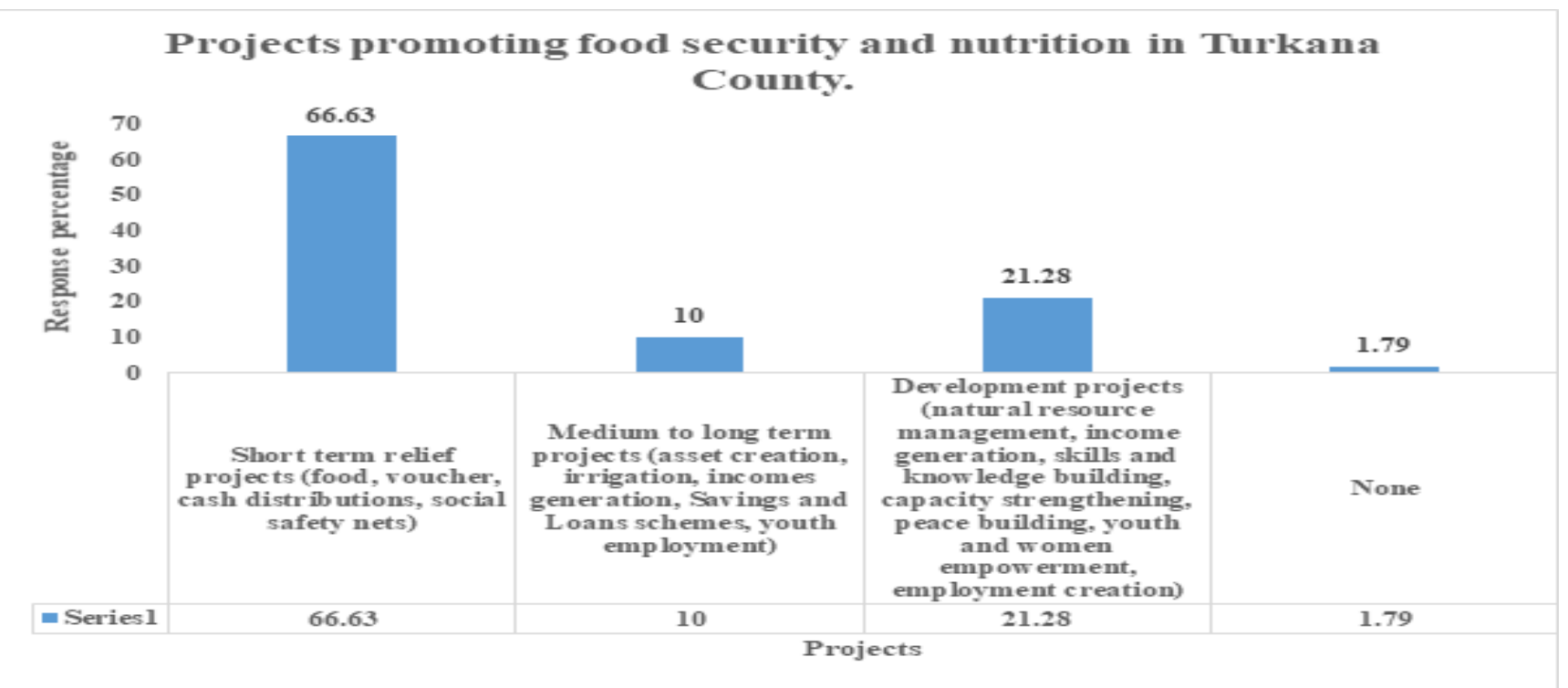

Figure 1: Projects promoting food security in Loima Sub-County 
On food availability component, the main aspect being investigated on food was functionality of markets involved in the food items. The major element about markets was price. Majority of the respondents were affirmative about this. Nonetheless some of the respondents were of the view that, as a result of cash injection into the local markets there were serious inflation rates. This could be explained by the fact that the cash transfers increased their purchasing power thus increasing demand for the food items.

The respondents were also asked to comment on whether the local markets were well functioning and whether all items needed were found. The responses on this aspect were mixed. Some of the respondents were of the view that some items that they needed were not there in the markets. Further a number complained that the markets are not always opened, rather there are specific days which markets do open up. These responses are a reflection of a mixed picture of preferences from the community members of Loima Sub County.

On food accessibility, food consumption scores were calculated for the households in the study using the food consumption frequency and the weights for each food categories. The food consumption score was categorised in poor (1-21), borderline (21.5-35) and acceptable (>35) (Table 3).

\section{Table 3: Household Food Consumption Score}

\begin{tabular}{ll}
\hline Food Consumption Status & Percentage (\%) \\
\hline Poor & 48.97 \\
Borderline & 29.23 \\
Acceptable & 21.79 \\
\hline Total & $\mathbf{1 0 0}$ \\
\hline
\end{tabular}

According to the result in (Table 3), 48.97\% of the households in Loima Sub-County have poor food consumption status with only $21.79 \%$ having acceptable food consumption status. This can be attributed to high poverty index exacerbated by high prevalence of food insecurity, drought and conflict. The pastoralism form of livelihood in Loima is frequently affected by droughts, flash floods, cattle rustling and livestock diseases. With effect on livelihoods, households remain depending on relief food for their survival. Sometimes relief foods received are less nutritiously dense food with low kilocalorie thus majority of the households recording poor food consumption status.

On food utilization dietary diversity score was used to analyse daily household diet. The findings are as presented in Table 4:

Table 4: Main Diet Consumed

\begin{tabular}{ll}
\hline Food Group & Percentage (\%) \\
\hline Main Staples (Cereals and oil) & $49 \%$ \\
Dairy products & $12 \%$ \\
Meat/Fish & $27 \%$ \\
Vegetables & $9 \%$ \\
Fruits & $3 \%$ \\
& \\
\hline Total & $\mathbf{1 0 0}$ \\
\hline
\end{tabular}

The results shown in (Table 4) shows that cereals and oil formed the main part of households' staple daily diet in Loima Sub-County. Fruits, vegetables and fish were least consumed. Other food consumed in the study area includes dairy products, and meat. High consumption of cereals and oil is attributed to the relief food supplied to the community. Loima is in a drought stricken area thus relief food is among the strategies used to support food security in the study area. Low consumption of fruits and vegetables can be explained by the harsh climatic condition that does not favour growing of fruits and vegetables. However, from the FGDs, members stated that these products were available in the local market although their prices were unaffordable to most of the locals.

\subsection{Correlation between collective community resilience capacity and performance of food security projects}

To find the link between collective community resilience capacity and performance of food security projects a correlation analysis of the variables was conducted to check the direction and magnitude of the relationship. The results of the correlation analysis are presented on Table 5. 
Table 5: Correlation of community resilience capacity and performance of food security projects

\begin{tabular}{llllll}
\hline & & $\begin{array}{l}\text { Social } \\
\text { capital }\end{array}$ & $\begin{array}{l}\text { Social } \\
\text { safety nets }\end{array}$ & $\begin{array}{l}\text { Disaster } \\
\text { management } \\
\text { skills }\end{array}$ & $\begin{array}{l}\text { Community } \\
\text { resource } \\
\text { capacity }\end{array}$ \\
\hline $\begin{array}{l}\text { Performance of food } \\
\text { security projects }\end{array}$ & $\begin{array}{l}\text { Pearson } \\
\text { Correlation } \\
\text { Sig. (2-tailed) }\end{array}$ & $0.3121^{*}$ & $0.1722^{*}$ & $0.3753^{*}$ & $0.3206^{*}$ \\
& $\mathbf{N}$ & 420 & 0.000 & 0.000 & 0.000 \\
& $\mathbf{N}$ & 420 & 413 & 420 \\
\hline
\end{tabular}

From (Table 5) above, all the variables of community resilience capacity were positively correlated with performance of food security projects in Loima Sub County. Disaster management skills had the highest correlation coefficient then followed by community resource capacity, social capital and finally social safety nets. The correlation of social safety nets was weak but for the other variables of community resilience capacity, correlation was moderate.

To analyse the contribution of the independent variables on performance of food security projects, regression was done under hypothesis of study. Data was analyzed using ordinary least square method; the results of the regression model are presented in (Table 6).

Table 6: Community resilience capacity and performance of food security projects

\begin{tabular}{|c|c|c|c|c|c|}
\hline \multicolumn{6}{|c|}{ Model Summary } \\
\hline Model & $\mathrm{R}$ & R square & $\begin{array}{l}\text { Adjusted } \\
\text { Square }\end{array}$ & & $\begin{array}{l}\text { Std. Error of the } \\
\text { Estimate }\end{array}$ \\
\hline & 0.458 & 0.1714 & 0.1633 & & 0.7629 \\
\hline
\end{tabular}

Predictors: (Constant) Social capital, Social safety nets, Disaster management skills, Community resource capacity

$\begin{array}{llllll}\begin{array}{l}\text { ANOVA } \\ \text { Model }\end{array} & \begin{array}{l}\text { Sum of } \\ \text { squares }\end{array} & \text { Df } & \text { Mean Square } & \text { F } & \\ \text { Regression } & 49.11 & 4 & 12.28 & 21.10 & 0.000 \\ \text { Residual } & 237.44 & 408 & 0.58 & & \\ \text { Total } & 286.55 & 412 & & & \end{array}$

Dependent Variable: Performance of Food Security Projects

Predictors: (Constant) Social capital, Social safety nets, Disaster management skills, Community resource capacity

\begin{tabular}{|c|c|c|c|c|c|}
\hline \multicolumn{6}{|l|}{ Coefficients } \\
\hline \multirow[t]{3}{*}{ Model } & \multirow{2}{*}{\multicolumn{2}{|c|}{$\begin{array}{l}\text { Standardized } \\
\text { Coefficients }\end{array}$}} & \multirow{2}{*}{\multicolumn{3}{|c|}{$\begin{array}{l}\text { Unstandardized } \\
\text { Coefficients }\end{array}$}} \\
\hline & & & & & \\
\hline & B & Std. Error & Beta & $\mathrm{T}$ & Sig. \\
\hline (Constant) & 3.8536 & 0.1745 & & 22.08 & 0.0000 \\
\hline Social capital & 0.0899 & 0.0630 & 0.0932 & 1.4300 & 0.1540 \\
\hline Social safety nets & 0.2274 & 0.0741 & 0.2307 & 3.0700 & 0.0020 \\
\hline $\begin{array}{l}\text { Disaster management } \\
\text { skills }\end{array}$ & 0.3240 & 0.0719 & 0.3273 & 4.5000 & 0.0000 \\
\hline $\begin{array}{l}\text { Community resource } \\
\text { capacity }\end{array}$ & 0.1759 & 0.0758 & 0.1792 & 2.3200 & 0.0210 \\
\hline
\end{tabular}

From (Table 6) all the variables under study produced an $r$ value of 0.458 ; this indicates that performance of food security projects has a moderate positive correlation with community resilience capacity. The adjusted $\mathrm{R}^{2}$ statistic is 0.1633 an indicator that community resilience capacity explains $16.33 \%$ of the variance in performance of food security projects in Loima Sub County while the other percentage is accounted by other variables not included in the research study. In terms of significance levels, the only variable that is not statistically significant is social capital since its $\mathrm{p}$ value $=0.1540$ is greater than the threshold of 0.05 . All the standardized beta coefficients are statistically significant at 5\% level of significance except social capital. The criterion is the p-value, in which case all the p-values are less than 0.05 . Among the indicators of community resilience capacity, disaster management 
seem to have the largest influence 0.3240 on performance of food security projects followed by social safety nets 0.2274 and finally community resource capacity 0.1759 . When all the factors are considered in unison, social capital seems to have no influence on performance of food security projects in Loima Sub County.

The F statistic of 21.10 was statistically significant at $5 \%$ level of significance $(p=0.000<0.05)$ implying that all the variables in unison are statistically important explanatory variables to performance of food security projects in Loima. The fact that they are statistically significant implies we have enough evidence to reject the null hypothesis and conclude that community resilience capacity has a significant influence on performance of food security projects in Loima Sub County, Kenya. This is illustrated by the following summative equation.

Where:

$$
Y=3.854+0.0899 X_{1}+0.2274 X_{2}+0.3240 X_{3}+0.1759 X_{4}
$$

$\begin{array}{lll}Y & = & \text { Performance of food security projects } \\ X_{1} & = & \text { Social capital } \\ X_{2} & = & \text { Social safety nets } \\ X_{3} & = & \text { Disaster management skills } \\ X_{4} & = & \text { Community resource capacity }\end{array}$

Table 7: Summary of Hypothesis Testing - Results

\begin{tabular}{|c|c|c|c|c|}
\hline Objective & Hypothesis & Results & Resulting Model & Conclusion \\
\hline $\begin{array}{l}\text { To establish the influence of } \\
\text { combined community resilience } \\
\text { capacity on performance of food } \\
\text { security projects in Turkana County, } \\
\text { Kenva }\end{array}$ & $\begin{array}{l}\text { Community resilience capacity has a } \\
\text { significant influence on the } \\
\text { performance of food security } \\
\text { projects in Turkana County, Kenya. }\end{array}$ & $\begin{array}{l}\text { Adjusted } R^{2}=0.1633 \\
F=21.10 \\
P=0.000<0.05\end{array}$ & $\mathrm{Y}=3.854+0.0899 \mathrm{X}_{1}+0.2274 \mathrm{X}_{2}+0.3240 \mathrm{X}_{3}+0.1759 \mathrm{X}_{4}$ & $\begin{array}{l}\text { Reject the null } \\
\text { hypothesis }\end{array}$ \\
\hline
\end{tabular}

\section{Discussion of Findings}

All the variables of community resilience capacity were positively correlated with performance of food security projects in Loima Sub County. Disaster management skills had the highest correlation coefficient with social safety nets having weak correlation coefficient.

In terms of disaster management skills, those households who adopted disaster management strategies were less likely to be trapped in food insecurity than those who don't adopt the strategy. In the study majority of the households heavily relied on external help during disasters, thus most food security projects in the area are aimed at cushioning the locals against the impacts of disasters. The findings of this study are affirmed by a UN-OCHA study on disaster management in Mozambique. Their findings showed that after the government of Mozambique had invested in disaster preparedness by issuing timely alerts and established contingency plans, the impact of the recurrent floods was relatively small in terms of the number of people who died (OCHA, 2013).

Social safety nets had weak positive correlation coefficient, which illustrate the challenges faced by the local community in accessing the safety nets. Some of the challenges include late disbursement, irregularities in disbursement as well as fewer amounts. The findings are in agreement with study on Productive Safety Net Program in Ethiopia which confirmed that the positive effects of the program were not robust enough to enhance resilience against the impacts of severe shocks despite its positive contribution to improve food consumption and wellbeing (Devereux and Teshome, 2013; John et al., 2013).

Despite agreement about the positive correlation of social capital on household resilience, existing studies show mixed results. For example, Kasie (2017) in his study on shock exposure to livelihoods in Ethiopia found that an increase in household participation in social networks decreases the probability of a household to be resilient. Kasie affirmed that an increase in participation of respondents in social networks decreases the likelihood of a household to saving or accumulate assets as a buffer against anticipated shocks.

\section{Conclusions}

Overall, this study concludes that community resilience capacity influence the performance of food security projects in Loima Sub-County, Turkana County, Kenya. More specifically, the following conclusions are made:

a) That all the variables of community resilience capacity were positively correlated with performance of food security projects in Loima Sub County. Disaster management skills had the highest correlation coefficient with social safety nets having weak correlation coefficient.

b) Those households with combined resilience capacity were less likely to be trapped in food insecurity than those who didn't adopt the strategies. Majority of the households were vulnerable, partly due to their overreliance on a single livelihood which is pastoralism.

c) That social safety net if not linked with other development programs is insufficient to address household food insecurity. 


\section{$5 \quad$ Recommendations}

Based on the findings of the study, the following recommendations were made:

a) A combination of investments on social capital, social safety nets, disaster management capacities and natural resource utilization should be made with a focus to addressing not only the short term food security needs of the vulnerable populations but the long term needs that will build resilience over time and reduce frequent exposure to shocks and stresses.

b) Food security project interventions should be inclusive and sustainable, as well as diversified. Diversified livelihoods are better placed for coping with shocks since communities have wider choices for alternative sources of living.

c) There is need to re-design social safety nets to cater for all the most vulnerable segments of the population. These cash transfers can be offered as incentive on condition that the recipients are participating in diverse food security projects.

d) There is need to strengthen the traditional/indigenous early warning systems and enhancing modern ways of disaster detection and communication to address chronic vulnerability to food insecurity.

\section{References}

Alinovi, L., D’Errico, M., Mane, E., Romano, D., (2010). Livelihoods strategies and household resilience to food insecurity: An empirical analysis to Kenya, in: Conference Organized by the European Report of Development, Dakar, Senegal, June. pp. 28-30.

Alonso B. E. (2015) The impact of culture, religion and traditional knowledge on food and nutrition security in developing countries. FOODSECURE Working paper no. 30 March 2015.

Barbier, B and Hochard, J. (2014).Poverty and the spatial distribution of rural population (SSRN) Scholarly Paper No. ID 2522735). Social Science Research Network, Rochester, New York.

Barrett, C. B., \&Constas, M. A. (2014).Toward a theory of resilience for international development applications. Proceedings of the National Academy of Sciences, 111, 14625-14630.

Behnke, R. H. (2008). The economic contribution of pastoralism: case studies from the horn of Africa and Southern Africa. Nomadic Peoples, 2008,12(1):45-79.

Brunson, J. (2017). Maternal, newborn, and child health after the 2015 Nepal earthquakes: an investigation of the long-term gendered impacts of disasters. Maternal and child health journal, 21(12), 2267-2273.

Chambers, R., Conway, G., (1992). Sustainable rural livelihoods: practical concepts for the 21st century. Institute of Development Studies (UK).

Constas, M., d'Errico, M., and Garbero, A. (2016). Quantitative analyses for resilience measurement. Guidance for constructing variables and exploring relationships among variables: Resilience measurement technical working group. Technical series no. 7.Food security information network. http://www.fsincop.net/fileadmin/user_upload/fsin/docs/resources/fsin_technicalseries_7.pdf.

Devereux, S. (2016). Social protection for enhanced food security in sub-Saharan Africa.Food Policy, 60, 52-62.

Devereux, S., Teshome, A., 2013. From Safety Nets to Social Protection: Options for Direct Support Beneficiaries of the Productive Safety Net Programme, in: Food Security, Safety Nets and Social Protection in Ethiopia. Forum for Social Studies: Addis Ababa.

Downing, T.E., and K. Bakker.(2000). Drought discourse and vulnerability. In Drought: A global assessment. Natural hazards and disasters series, Vol. II, ed. D.A. Chapter 45: 3-18. London: Routledge.

Eliyahu M. Goldrat T. (1984), The Goal geared to help projects achieve their goals. The theory of constraints.

Fan, S., Pandya-Lorch, R., \&Yosef, S. (2014). "resilience for food and nutrition security, " international food policy research institute (IFPRI). Washington, DC.

FAO.(2008). Food Security in Protracted Crises. What can be done? Food Security Information for Action (FSIA).Policy Brief.

Frankenberger, T., Langworthy, M., Spangler, T., Nelson, S., Campbell, J., \&Njoka, J. (2012). Enhancing resilience to food security shocks. White Paper (Draft). Tucson: TANGO International.

Heale, R., \&Twycross, A. (2015).Validity and reliability in quantitative studies.Evidence-based nursing, ebnurs2015.

Holling, C. S. (1973). Resilience and stability of ecological systems. Annual Review of Ecology and Systematics, 4, $1-23$.

John, F., Sabates-Wheeler, R., Berhane, G., Handino, M., Kumar, N., Lind, J., Taffesse, A.S., Tefera, M.H., (2013).Implementing large scale food security programs in rural Ethiopia.Forum for Social Studies (FSS).

Kasie,T., (2017). Shock exposure, livelihood strategies \& risk response options: the case of Tach-Gayint District, Amhara Region, Ethiopia. Unpublished Doctoral Thesis, University of Jaume I.

Maxwell, S., Smith, M., others, (1992). Household food security: a conceptual review. Househ.Food Secur. Concepts Indic. Meas. Ed. Maxwell T Frankenberger Rome N. Y. IFAD UNICEF. 
Mertens, D. M. (2014). Research and evaluation in education and psychology: Integrating diversity with quantitative, qualitative, and mixed methods. Sage publications.

Miller, F., Osbahr, H., Boyd, E., Thomalla, F., Bharawani, S., Ziervogel, G., Walker, B., Birkmann, J., Van der Leeuw, S., Rockström, J., others, (2010). Resilience and vulnerability: complementary or conflicting concepts? Ecol. Soc. 15, 1-25.

Morgan-Lopez, A. A., \& MacKinnon, D. P. (2006). Demonstration and evaluation of a method for assessing mediated moderation. Behavior research methods, 38(1), 77-87.

Nyanjom O, (2014). Re-marginalizing Kenyan Pastoralists: The Hidden Curse of National Growth and Development, Kenya Institute for Public Policy Research and Analysis.

Opiyo, F., Wasonga, O., Nyangito, M., Schilling, J., \&Munang, R. (2015).Drought adaptation and coping strategies among the Turkana pastoralists of northern Kenya.International Journal of Disaster Risk Science, 6(3), 295-309.

Pasteur, K., (2011). From Vulnerability to Resilience, a framework for analysis and action to build community resilience.Practical Action Publishing.

Quandt, A. (2018). Measuring livelihood resilience: The Household Livelihood Resilience Approach (HLRA).World Development, 107, 253-263.

Resilience Alliance, n.d. Resilience Alliance-Publications [WWW Document].URL http://www.resalliance.org/publications/565.

Sophie, S. and Katsushi S. (2019) Does the Hunger Safety Net Programme reduce multidimensional poverty? Evidence from Kenya, Development Studies Research, 6:1, 47-61, DOI: 10.1080/21665095.2019.1582347.

Tolossa, D. (2018). Pathways of Livelihood Transformation among Borana of Southern Ethiopia. Eastern Africa Social Science Research Review, 34(1).

Toth, A., Rendall, S., \&Reitsma, F. (2016). Resilient food systems: A qualitative tool for measuring food resilience. Urban Ecosystem, 19, 19-43.

UN-OCHA, (2013), Mozambique disaster trends assessment, UN-Office of Coordination of Humanitarian Affairs.risk management.

USAID.(2011). Enhancing resilience in the Horn of Africa:Anevidence-based workshop on strategies for success. USAID Workshop Proceedings. December 13-14, 2011.

Vaitla, B., Tesfay, G., Rounseville, M., \& Maxwell, D. (2012). Resilience and livelihoods change in Tigray, Ethiopia. Somerville: Tufts University, Feinstein International Center.

Von Braun, J., Teklu, T., Webb, P., (1999). Famine in Africa: Causes, responses, and prevention. Intl Food Policy Res Inst.

Walker, B., Gunderson, L., Kinzig, A., Folke, C., Carpenter, S., Schultz, L., (2006).A handful of heuristics and some propositions for understanding resilience in social-ecological systems.Ecol. Soc. 11, 13. 